\title{
Export Barriers and Export Performance of Vietnamese Seafood Firms Targeting International Markets
}

\author{
TRAN HUU AI \\ Van Hien University - aihuutran@gmail.com \\ HO HUY TUU \\ Nha Trang University - tuu_hohuy@yahoo.com \\ TRAN VAN HAU \\ Van Hien University - hau@vhu.edu.vn
}

\section{ARTICLE INFO ABSTRACT}

Article history:

Received:

Apr. 92015

Received in revised form:

Aug. 182015

Accepted:

Sep. 152015

Keywords:

Export barriers, export performance, seafood industry, Vietnam.
The purpose of this paper is to identify key export barriers and their impact on performance of Vietnamese seafood firms with their export to the US market. By reviewing the literature and using expert opinions, five factors of the export barriers can be identified, including product, price, distribution, logistics, and promotion. A structured questionnaire is used to survey managers of 152 seafood firms, and exploratory factor analysis, used to categorize variables in five barrier dimensions. Then, the development of linear regression aims to determine which barrier has a greater negative effect on export performance. The empirical results suggest that except for promotion, the other barriers have significantly negative impact on export performance. Based on the relative importance of the different marketing barriers, seafood firms should firstly focus on quality improvements to improve their performance. 


\section{Introduction}

The structure of the seafood industry has changed significantly in recent years as changes in technology have promoted globalization in the industry. Technological advances in communication and transportation have been reducing transaction costs, improving the ease of access to markets around the world. As a result, international trade in seafood increased first by $25 \%$ in the 2000 s, followed by a significant global trade boom of $50 \%$ growth from 2000 to 2013. Over 60\% of that growth is contributed to market access in developing countries (Gehlher \& Dohlman, 2009).

Export as an important economic activity to a firm and a driver of economic development of a nation has widely been acknowledged. In spite of numerous benefits of exporting, most firms do not export despite exporting being considered as inevitable in the increasingly integrated world markets (Papadopoulos \& Martin, 2010). Although the benefits are derived from exporting in an increasingly globalized marketplace, for many smaller-sized manufacturers the internationalization path is beset by a range of obstacles. In particular, marketing barriers, such as product, price, distribution, promotion, and logistics, occupy an important position because these often cause financial losses and negative attitudes toward international activities (Leonidou et al., 2002; Balabanis, 2000).

The key role of exporting in national economies has resulted in export performance attracting considerable interest in many studies. Most research focuses on the relationships between performance and organizational or environmental factors; less has been done into the specific factors that could hinder exporting. The determinants of the export performance of small and medium-sized firms are of vital importance for policy makers, firm managers, and researchers (Baldauf et al., 2000; Katsikeas et al., 2000; Sousa \& Bradley, 2008). While most research focusing on export performance has been undertaken in the United States and Europe, limited work has been conducted in developing countries. Enhancing export performance is crucial for firms based in developing countries that view the global marketplace as a means to ensure growth, survival, or competitiveness (Matanda \& Freeman, 2009). 


\section{Literature review}

There is a growing block of literature on the impact of both globalization and regional integration agreements on international business as well as on the issue of internationalization of firms via exporting (Falbe \& Welsh, 1998; Pett \& Wolff, 2000, 2003). Studies that identify problems firms are facing in exporting are scarce and relatively outdated and do not address the changing business environment as a result of increasing bilateral and regional trade agreements (Gripsrud, 1990; Ramaswami \& Yang, 1990). The European Union (EU) and India are presently negotiating a free trade agreement (FTA), which aims to eliminate tariffs within a seven-year time frame with the target implementation dates of 2010-2011. Such an agreement could transform the overall business environment from the interconnectedness of these trading economies. Bilkey (1978) suggested that if trade agreements between countries and/or economic blocs are to achieve their potential and bestow benefits, public policy may be required to help firms in overcoming export problems.

\subsection{Export performance}

Export performance has been a widely studied concept in international business literature (Shoham, 1999). Export performance, in both past and present terms, is essential to the survival of the organization in diverse ways. While past performance motivates managerial strategy actions, present performance signals the effectiveness of management strategy modifications as well as set forth new strategy actions (Lages et al., 2008). There are many different perspectives on performance. The concept of performance has changed over time and expanded with the development of production management, and it is also a theme that has been concerning technicians, sociologists, economists, and most managers for many years. Technically speaking, efficiency, as a ratio between output and input, measures performance-using resources to produce the required output. However, this can lead to focus on quantity, whereas little attention is paid to qualitative aspects.

In addition, with the flurry of studies conducted over the years scholars are yet to generally agree on the conceptual as well as operational definitions of the concept. Operational definitions of export performance vary across the existing literature. Some scholars, including Ahmed et al. (2004), define export performance through export efficiency, export effectiveness, and continuous engagement in export. Others (Koh, 
1991; Bilkey, 1982) refer to export performance through a construct that measures export intensity, perceived export profitability, and continuous export activity. It is the latter construct that would form the basis of export performance measurement in the next sections of this study. According to Shoham (1999), a conceptual definition of export performance should address two parts: export and performance.

Export performance is regarded as one of the key indicators of success of a firm's operations. Research into export performance has grown considerably during the past few decades (Ibeh, 2004). While numerous studies have been conducted to explain export performance and its antecedents, there is no generally accepted conceptualization. Export performance represents the outcome of a firm's activities in export markets (Papadopoulos \& Martin, 2010), and it can also be defined as the outcomes from the firm's international activities. From this perspective export performance is the extent to which the firm achieves its objectives when exporting a product to a foreign market (Navarro et al., 2010).

\subsection{Export barriers}

Export barriers can be defined as the attitudinal, structural, operational, and other constraints that hinder a firm's ability to initiate, develop, or sustain international operations (Koksal \& Kettaneh, 2011). It is important to achieve a better understanding of export barriers, since these barriers waste the resources and threaten the efficiency and effectiveness of a firm's operations. The negative impact that export barriers can have on SMEs' internationalization behaviors and activities has attracted the attention of many researchers in international business (Ortega, 2003; da Silva \& da Rocha, 2001). Those studies have employed different perspectives to establish a set of notable barriers, especially with regard to specific industry or geographical area.

There are so many difficulties in foreign trade, some of which are as follow: (i) lack of awareness of export opportunities (data barriers); (ii) lack of managerial resources; (iii) lack of non-managerial human resources; (iv) financial resources (investment) barriers; (v) production related barriers; (vi) technical barriers; (vii) competitive barriers; (viii) distributive barriers; (ix) official rituals and instructions barriers; (x) payment barriers; (xi) currency price barriers; (xii) regulatory (regulations) barriers; and (xiii) governmental and cultural barriers.

Leonidou (2004) classified export barriers into internal organizational barriers and external organizational barriers that affect a firm's export activities. Internal barriers 
have been shown to include management related difficulties, distribution problems, document related problems, lack of knowledge, and other social, cultural, and managerial factors. On the other hand, external barriers root on the environments outside exporters' firms (Leonidou, 2004, Testom \& Lutz, 2006).

The results of various studies have indicated that exporters' sensitivity to the barriers of foreign markets is determined through managerial perception that in turn is affected by underlying factors in relation to the size, resources, and capability of a company and its partnership in export and its international analysis (Barney, 1991; Suarez-Ortega, 2003). Exporters are also found to consider high bank profits and use of low potentials and weak technology as big problems that affect their business performance (OwusuFrimpong \& Mmeih, 2007). In general conditions changes in consumers' preferences, existence of brokers and agents, import tariffs, risk of losing money in foreign markets, and safety and quality standards are other barriers to exports of companies (Rabino, 1980; Korth, 1991).

\subsection{Marketing barriers}

Marketing barriers refer to the obstacles in a firm's overseas activities, such as product quality, price, distribution, logistics, and promotion (Karelakis et al., 2008; Sousa \& Bradley, 2008). The overall review in Table 1 illustrates a comprehensive picture of the effects of those marketing barriers on export performance.

\section{Table 1}

Literature review on/related to effects of marketing barriers on export performance

\begin{tabular}{lcccccc}
\hline \multicolumn{1}{c}{ Literature review } & $\begin{array}{c}\text { Industrial } \\
\text { sector }\end{array}$ & $\begin{array}{c}\text { Product } \\
\text { barrier }\end{array}$ & $\begin{array}{c}\text { Price } \\
\text { barrier }\end{array}$ & $\begin{array}{c}\text { Distribution } \\
\text { barrier }\end{array}$ & $\begin{array}{c}\text { Promotion } \\
\text { barrier }\end{array}$ & $\begin{array}{c}\text { Logistics } \\
\text { barrier }\end{array}$ \\
\hline Leonidou (2000) & M & X & & X & & X \\
Karelakis et al. (2008) & O & X & X & & & \\
Sousa and Bradley (2008) & M & & X & & X & X \\
Kaynak and Kothari (1984) & M & & X & X & & \\
Czinkota and Ursic (1983) & M & & X & & & X \\
Barrett and Wilkinson (1985) & M & X & X & & &
\end{tabular}




\begin{tabular}{lcccccc}
\hline \multicolumn{1}{c}{ Literature review } & $\begin{array}{c}\text { Industrial } \\
\text { sector }\end{array}$ & $\begin{array}{c}\text { Product } \\
\text { barrier }\end{array}$ & $\begin{array}{c}\text { Price } \\
\text { barrier }\end{array}$ & $\begin{array}{c}\text { Distribution } \\
\text { barrier }\end{array}$ & $\begin{array}{c}\text { Promotion } \\
\text { barrier }\end{array}$ & $\begin{array}{c}\text { Logistics } \\
\text { barrier }\end{array}$ \\
\hline Kedia and Chhokar (1986) & M & X & X & & X & X \\
Moini (1998) & M & & X & X & & \\
Cheong and Chong (1988) & M & X & & & X & \\
Keng and Jiuan (1989) & M & X & X & X & X & \\
Bauerschmidt et al. (1985) & O & X & & X & & X \\
\hline
\end{tabular}

Notes: * reversed scale; M: multiple industries; O: one industry

Generally, marketing barriers have been found to negatively affect export performance in most previous studies. Technical barriers to trade (TBTs) exist in most industries but are particularly widespread in the international exchange of primary and processed agricultural and aquaculture products. Recently, a considerable number of Vietnamese seafood products have been rejected at US ports because they failed to comply with its regulations on environmental amenities, food safety, and so forth, thus causing significant losses to Vietnamese producers and exporters. The aim of this paper is to discuss TBTs that have been applied to Vietnam's seafood products as means of import restriction, and also to evaluate the effects of marketing barriers on Vietnamese seafood exported to the US market. The resolutions of this problem will contribute to the Vietnamese business community, assisting them to expand the volume of its trade with the U.S and gain a solid foothold in this important market. However, empirical evidence has often been found using data from multiple industries and investigating only one or two kinds of marketing barriers.

Product barrier occurs in the stage of developing new products for foreign markets, meeting export product quality standards, adapting export product design/styles, and providing an after-sales service (Kaleka \& Katsikeas, 1995; Leonidou, 2000, 2004). Small and medium-sized firms often lack managerial expertise, research skills, R\&D competence, and financial resources, which limits the firms' fulfillment of the highquality standards for products required by foreign markets (Leonidou, 2004). Different facets of the product barrier have been found to impact differently on export performance. Some facets have a very low impact (e.g., developing new products for foreign markets), while others have a low (e.g., meeting export product quality 
standards) to moderate influence (e.g., providing a technical/after-sales service) on export performance (see Leonidou, 2004 for a review). Generally, the relative role of products barriers is the weakest among the marketing barriers to the export performance of small and medium-sized firms across industries (Leonidou, 2004).

Price barrier involves offering satisfactory prices to customers and the difficulty in matching competitors' prices and granting credit facilities to foreign customers (Kedia \& Chhokar, 1986; Moini, 1998; Leonidou, 2004). Small and medium-sized firms often suffer high costs due to the lack of economies of scale, causing them to face difficulties in controlling their exporting operations. The aspects of the price barrier are documented to have a high (or very high) impact on export performance, and among the marketing barriers it is the strongest predictor of export performance (Leonidou, 2004).

Distribution barrier refers to complex foreign distribution channels, accessing export distribution channels, obtaining reliable foreign representation and maintaining control over foreign middlemen, and facing difficulties in supplying inventory abroad (Leonidou, 1995, 2004). The complexity and length of foreign distribution channels makes it difficult for firms to enter international markets. Small and medium-sized firms face a very low to a high impact of the different facets of the distribution barrier on their export performance. For example, while accessing export distribution channels and obtaining reliable foreign representation have an enormous influence, maintaining control over foreign middlemen has only a very small effect on export performance (Leonidou, 2004).

Logistics barrier is considered as an extensive dimension of the distribution barrier (Kaleka \& Katsikeas, 1995). The logistics barrier reflects the difficulties in supplying inventory in overseas markets, unavailable foreign warehousing facilities, and excessive transportation and insurance costs (Kaynak \& Kothari, 1984). The lack of financial and human resources and a large geographical distance generate many problems for the firms in delivering products on time as well as maintaining the reasonable storage of products abroad. Most small and medium-sized firms feel that the excessive transportation/insurance costs are a major problem, while supplying inventory and warehousing facilities abroad is popular but relatively weak (Leonidou, 2004).

Promotion barrier, finally, deals with adjusting export promotional activities to individual foreign market requirements in connection with the variations in buying motives, consumption patterns, and government regulations (Howard \& Borgia, 1990; 
Leonidou, 2004). The lack of resources and geographical distance also generate difficulties in adjusting export promotional activities. However, the effect of the promotion barrier on export performance for small and medium-sized firms is at a moderate level (Leonidou, 2004).

\section{Table 2}

Measures of the variables in the model proposal

\begin{tabular}{ll}
\hline \multicolumn{1}{c}{ Measure } & \multicolumn{1}{c}{ Sources } \\
\hline Product barrier & Howard and Borgia, 1990; Kaleka and Katsikeas, 1995; Leonidou, 2000, 2004 \\
Price barrier & $\begin{array}{l}\text { Barrett and Wilkinson, 1985; Kedia and Chhokar, 1986; Keng and Jiuan, 1989; } \\
\text { Moini, 1997; Leonidou, 2004 }\end{array}$ \\
$\begin{array}{l}\text { Distribution } \\
\text { barrier }\end{array}$ & Bauerschmidt et al., 1985; Keng and Jiuan, 1989; Leonidou, 1995, 2004 \\
$\begin{array}{l}\text { Logistics barrier } \\
\text { Promotion } \\
\text { barrier }\end{array}$ & Kaynak and Kothari, 1984; Barrett and Wilkinson, 1985; Leonidou, 2004 \\
$\begin{array}{l}\text { Enterprise } \\
\text { performance }\end{array}$ & Sullivan and Bauerschmidt, 1989; Howard and Borgia, 1990; Leonidou, 2004 \\
\hline
\end{tabular}

\section{Theoretical model and hypotheses}

Based on the above discussions, this study explores whether different categories of marketing barriers (product, price, distribution, logistics, and promotion) influence export performance simultaneously in the context of one industry. Because different industries have different success factors and drivers of export performance (Leonidou, 2004), a comparison within one specific industry can be more reliable for the firms or managers within this industry. The following hypotheses are suggested:

$\mathrm{H}_{1}$ : Product barrier has a negative effect on export performance.

$\mathrm{H}_{2}$ : Price barrier has a negative effect on export performance.

$\mathrm{H}_{3}$ : Distribution barrier has a negative effect on export performance.

$\mathrm{H}_{4}$ : Logistics barrier has a negative effect on export performance.

$\mathrm{H}_{5}$ : Promotion barrier has a negative effect on export performance. 
In order to prioritize the different categories of marketing strategies, it is important to gain an insight into the relative role of those marketing barriers in export performance for a specific industry (Leonidou, 2004). This study expects that price barrier has the strongest impact, then distribution, logistics, promotion, and finally product barrier with the weakest impact on export performance. The theoretical model is shown in the figure below.

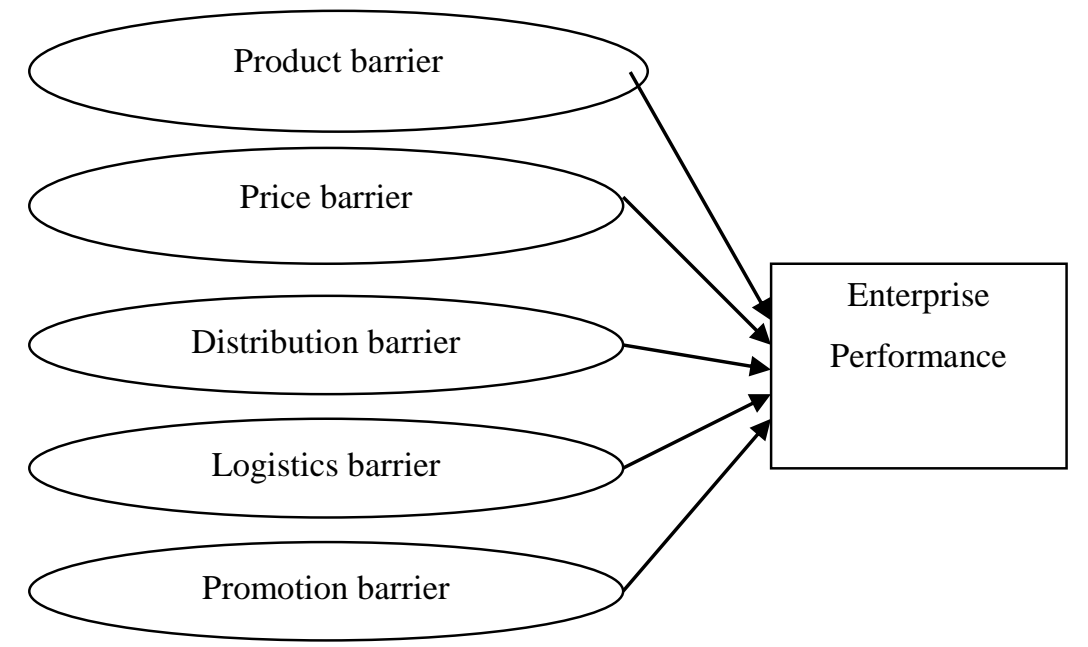

Figure 1. Theoretical model

Scales of the variables are adjusted to meet the conditions of Vietnamese seafood exporters based on in-depth interviews with experts and business managers.

The theoretical model covers five independent variables measured by 24 observed variables and one dependent variable measured by four observed variables. The results of measurement model are applied for all scale variables to access Cronbach's Alpha coefficients.

Scale of product barrier (S1) is measured by six observed variables, whose content refers to the development of new products for foreign markets.

Scale of price barrier (S2) is measured by four observed variables, whose content refers to the process of offering satisfactory prices to customers and the difficulty in matching competitors' prices.

Scale of distribution barrier (S3) is measured by five variables, whose content refers to complex foreign distribution channels and access to export distribution channels. 
Scale of logistics barrier (S4) is measured by five variables, whose content refers to the extensive dimension of distribution barrier.

Scale of promotion barrier (S5) is measured by four observed concepts, whose content refers to adjustment of export promotional activities targeting foreign markets.

Scale of enterprise performance (F) includes certain levels where companies meet customers' requirements for product quality, measured by four observed concepts, whose content involves how firms provide customers with good products to satisfy their demands.

Export performance is regarded as one of the key indicators of business success, and it can also be defined as the outcomes achieved from the firm's exporting products to a foreign market (Navarro et al., 2010).

\section{Methodology}

\section{Procedure for data collection}

With the primary aim of investigating the relationship between export barriers and export performance, an empirical analysis was conducted of Vietnam's firms that target US as the market for their products. Since the majority of studies about international business and export performance have been carried out in the US and Europe, there is a need for studies from developing countries to improve their poor export performance. On the other hand, with regard to volume of bilateral trade, Vietnam is a significant commercial partner for US in the ASEAN. Trade between Vietnam and US shows significant fluctuations in the trade balance.

Thus, focusing on this industry is expected to generate a comprehensive view of the role of marketing barriers in Vietnam's export performance. Seafood companies operate all along the coastal provinces of Vietnam with exporting markets covering over 165 nations and geographical areas. In preparation for this research we focused on three key exported products: pangasius, shrimp, and surimi. About 200 seafood companies fulfil the criteria and operate mainly in the south of Vietnam.

Quantitative research methods are applied in this study. The theoretical model includes five independent concepts measured by 25 observed ones and one dependent concept measured by three observed ones; multivariate scale is to be investigated. The observed concepts are measured on a five-point Likert scale. To ensure that the 
questionnaire's content and design would be unambiguously understood by the respondents, it was pre-tested by 12 experts (four academic professors in the international business field, four consultants in exporting and international business, and four managers from Vietnam's respected export firms). Having been revised in light of their comments, the questionnaire was then mailed to the managers of 200 seafood firms, each with a total of over 300 employees (those with fewer than 300 ones were ignored as their size is believed to be too small to contribute significantly to the export activities). In order to increase the response ratio, the firms' managers were contacted by phone to confirm their participation in the survey. Of the 200 questionnaires dispatched 152 usable responses were received, representing an effective response rate of $76 \%$. Statistical analyses were done in two phases: first, an explanatory factor analysis was performed, and then a structural equation model employed to determine which type of barrier has a greater effect on export performance, along with the use of SPSS 22.0 as statistical software for the analyses.

Description of the survey

The data collected from 152 seafood exporters in Vietnam with defining characteristics are presented in Table 3.

\section{Table 3}

Characteristics of Vietnam's seafood exporters in the sample

\begin{tabular}{lcc}
\hline Ownership & Quantity & Percentage \\
\hline Stock enterprises & 64 & 42.11 \\
Private enterprises & 88 & 57.89 \\
Size & Quantity & 100.00 \\
$300-500$ employees & 84 & 55.26 \\
Over 500 employees & 68 & 44.74 \\
Total & 152 & 100.00 \\
\hline
\end{tabular}

\section{Reliability and validity}

First, before factor analysis a reliability analysis of the scales is performed through Cronbach's Alpha. The rate of reliability of the questionnaire is 0.775 , which is within an acceptable range. Thus, the studied scales have a rather high level of internal 
consistency and are accordingly reliable. The concept scales are preliminarily assessed and screened by EFA method and Cronbach's Alpha coefficient for each component. Selection criteria are satisfactory when the following conditions are met: (i) coefficient of item-total correlation $>0.30$; (ii) Cronbach's Alpha coefficient $>0.60$; (iii) system load factor (factor loading) $>0.40$; and (iv) total variance extracted $\geq 50 \%$ (Hair et al., 1998).

\section{Table 4}

KMO measure and Bartlett's test

KMO and Bartlett's test

Kaiser-Meyer-Olkin measure of sampling adequacy.

0.793

Bartlett's test of sphericity

Approx. Chi-squared

1209.111

df 190

sig.

0.000

The results of the EFA, summarized in Table 5, show that 24 variations are observed in five components of the enterprise performance scale and five factors with 20 observed concepts are retained. There are four items of the observed concepts to be excluded, including product barrier6, price barrier4, distribution barrier4, and distribution barrier5.

After elimination of the four concepts, the EFA results indicate five factors of enterprise scale. As KMO coefficient $=0.793$, EFA matches the data and Bartlett's chisquare test value of 1209.111 at 0.000 significance level. Thus, the observed concepts are correlated with each other considering the overall scope. The variance extracted of 64.903 shows that the factors derived from $64.903 \%$ of explained variance of the data, eigenvalues in the system of 1.247. Therefore, the scale draw is acceptable. The scales have observed concepts excluded by EFA; Cronbach's Alpha coefficients are recalculated, and the results satisfy reliability requirements. 


\section{Table 5}

Constructs, factor loadings, and reliability (EFA)

\begin{tabular}{lccccc}
\hline \multicolumn{4}{c}{ Rotated component matrix } \\
\hline & \multicolumn{4}{c}{ Component } \\
\cline { 2 - 5 } & 1 & 2 & 3 & 4 & 5 \\
\hline Logistics barrier1 & 0.769 & & & & \\
Logistics barrier2 & 0.738 & & & \\
Logistics barrier3 & 0.824 & & & \\
Logistics barrier4 & 0.784 & & & \\
Logistics barrier5 & 0.758 & & & \\
\hline
\end{tabular}

Product barrier1

0.794

Product barrier2

0.747

Product barrier3

0.742

Product barrier4

0.564

Product barrier5

0.678

Promotion barrier1

0.761

Promotion barrier2

0.671

Promotion barrier3

0.726

Promotion barrier4

0.726

Price barrier1

0.810

Price barrier2

0.879

Price barrier3

0.834

Distribution barrier1

0.790

Distribution barrier2

0.874 


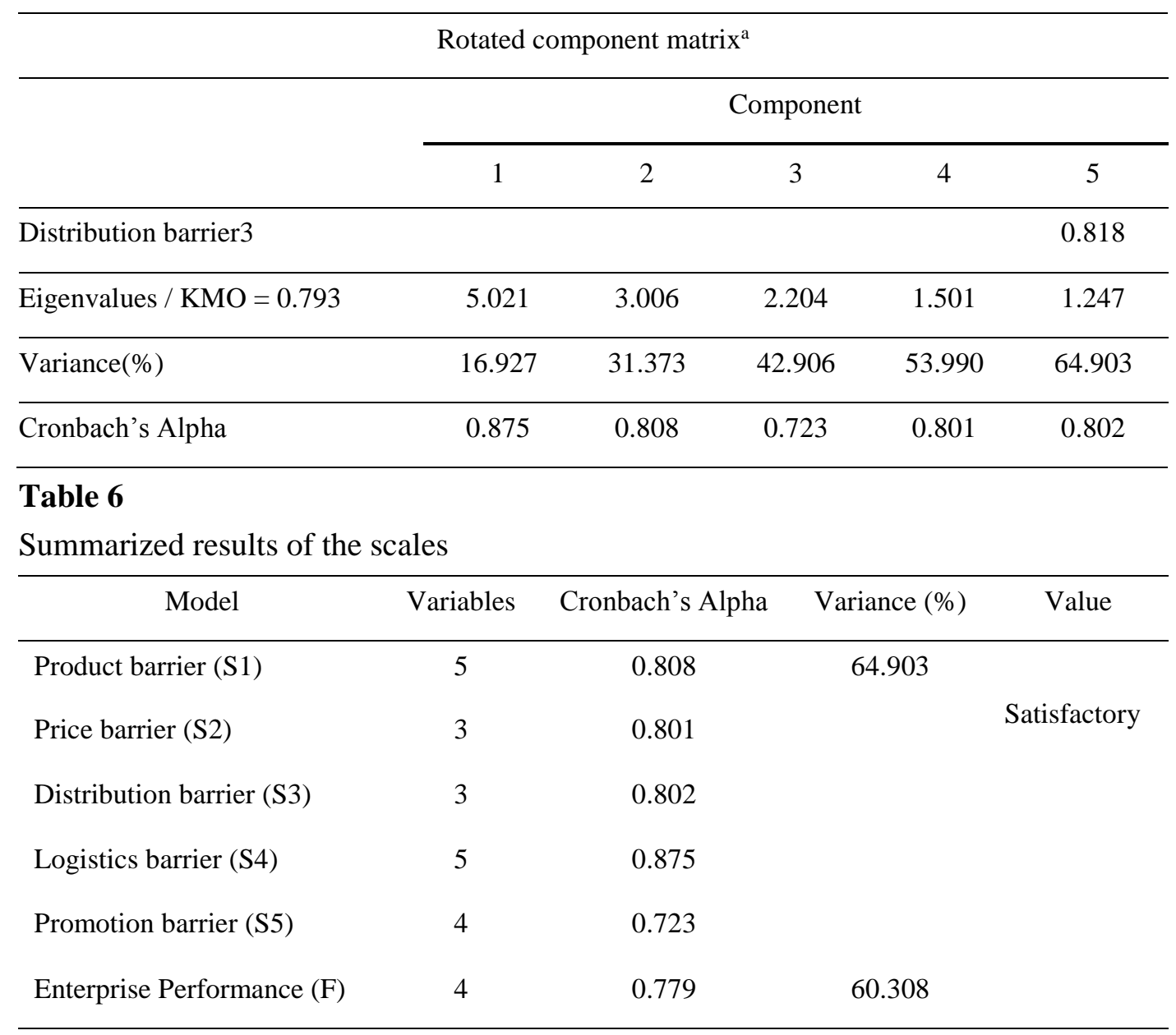

\section{Analysis of the correlation matrix}

The first step of conducting linear regression analysis is to consider the linear correlation between all the concepts or the overall relationship between each independent variable with the dependent variable, and between the independent concepts (Hoang \& Chu, 2008). 


\section{Table 7}

Correlations between the components

\begin{tabular}{lllllllll}
\hline Constructs & Mean & S.D & 1 & 2 & 3 & 4 & 5 & 6 \\
\hline 1. Export performance & 4.10 & 1.49 & - & & & & \\
2. Product barrier & 3.88 & 1.29 & $-0.49^{* *}$ & - & & & \\
3. Price barrier & 4.05 & 1.45 & $-0.02^{* *}$ & $0.04^{* *}$ & - & & \\
4. Distribution barrier & 4.12 & 1.91 & $-0.68^{* *}$ & $0.57^{* *}$ & $0.05^{* *}$ & - & \\
5. Logistics barrier & 3.72 & 1.39 & $0.07^{* *}$ & $-0.56^{* *}$ & $0.07^{* *}$ & $0.97^{* *}$ & - & \\
6. Promotion barrier & 4.20 & 2.09 & $-0.04^{* *}$ & $0.06^{* *}$ & $-0.03^{* *}$ & $0.09^{* *}$ & $0.07^{* *}$ & - \\
\hline
\end{tabular}

Notes: Correlations in bold are significant at $\mathrm{p}<0.05$.

\section{Regression analysis}

The estimated results of the multiple regression model indicate a good fit of the data $\left(\mathrm{F}=31.470, \mathrm{p}<0.001 ; \mathrm{R}^{2}=50.2 \%\right.$; all VIF $\left.<2.0\right)$. The results of testing the effects of marketing on export performance are shown in Table 8. It is expected that the product, price, distribution, logistics, and promotion barriers negatively affect export performance.

\section{Table 8}

Effects of marketing barriers on export performance

\begin{tabular}{lcccccccc}
\hline & \multicolumn{2}{c}{$\begin{array}{c}\text { Unstandardized } \\
\text { coefficients }\end{array}$} & $\begin{array}{c}\text { Standardized } \\
\text { Independent variable }\end{array}$ & & & \multicolumn{2}{c}{$\begin{array}{c}\text { Collinearity } \\
\text { statistics }\end{array}$} \\
\cline { 2 - 4 } & B & Std. error & Beta & & & Sig. & Tolerance & VIF \\
\hline (constant) & 1.341 & 0.440 & & 3.047 & 0.003 & & \\
Product barrier & -0.112 & 0.074 & -0.108 & -1.513 & 0.032 & 0.651 & 1.535 \\
Price barrier & -0.327 & 0.051 & -0.130 & -2.527 & 0.039 & 0.993 & 1.007 \\
Distribution barrier & -0.219 & 0.056 & -0.222 & -2.348 & 0.028 & 0.858 & 1.166
\end{tabular}


Logistics barrier

$-0.451 \quad 0.072$

$-0.156$

$-4.097 \quad 0.000$

0.633

1.579

Promotion barrier

$0.104 \quad 0.063$

0.101

$1.643 \quad 0.103$

0.870

1.150

Notes: $* \mathrm{p}<0.05 ; * * \mathrm{p}<0.01$; ns: non-significant; all VIF $<2.0 ; \mathrm{R}^{2}$ (export performance) $=50.2 \%$; $\mathrm{F}=31.470, \mathrm{p}<0.001$.

Table 8 shows that the dependent variable features quite strong linear correlation in the sense $\alpha>0.05$ with five independent concepts S1, S2, S3, S4, and S5. Since all absolute correlation coefficients between the concepts are in the range of 0.633 to 0.993 , satisfying $-1 \geq \mathrm{r} \geq+1$, all concepts satisfy the rule of multiple linear regressions.

This proves that the values achieve distinction, or in other words, the scales can possibly measure different variables in this study. Correlation matrix also shows that the variables of distribution barrier have the strongest negative impact, as opposed to promotion barrier, with the weakest impact on the dependent variable of enterprise performance.

Table 8 also indicates that all the four factors S1, S2, S3, and S4 of scale factors have a negative impact on export performance $(F)$ at the means sig $=0000-0039<0.05$. The remaining factor S5 ( $\mathrm{sig}=0.101$ ) is not statistically significant. Thus, it is concluded that the hypotheses H1 (S1), H2 (S2), H3 (S3), and H4 (S4) can be accepted. The regression equation for these variables with unstandardized coefficients takes the following form:

$$
\mathrm{F} 1=-0.112 * \mathrm{X} 1-0.327 * \mathrm{X} 2-0.219 * \mathrm{X} 3-0.451 * \mathrm{X} 4+0.104 * \mathrm{X} 5
$$

where F1 denotes enterprise performance, and X1, X2, X3, X4, and X5 denote product, price, distribution, logistics, and promotion barriers respectively. 


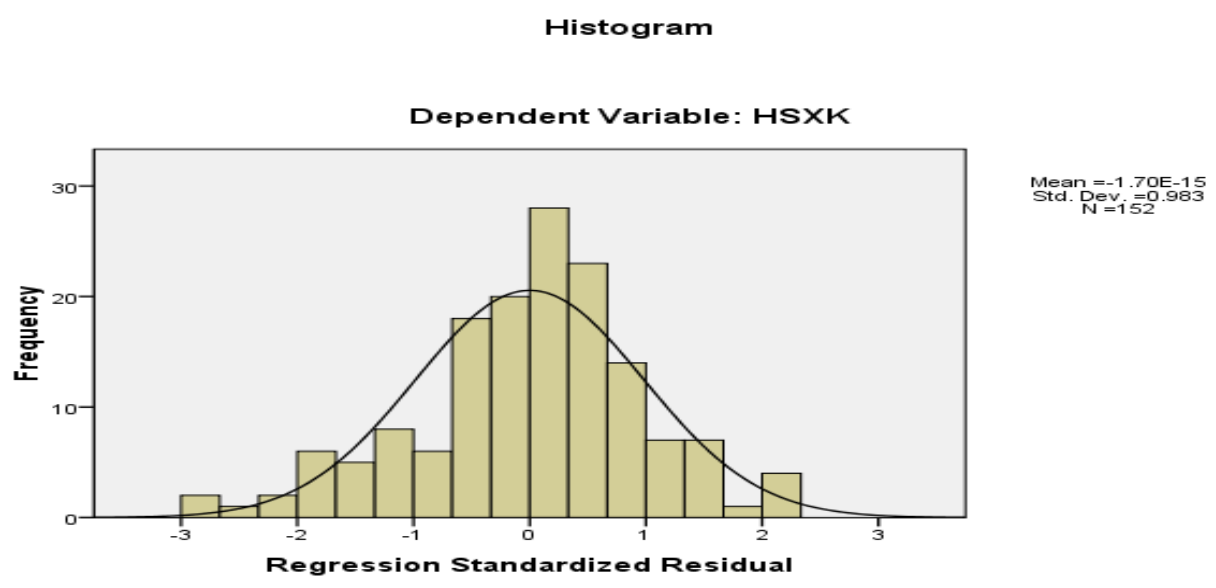

Figure 2. Regression standardized residual.

\section{Assuming normal distribution of residuals}

According to the analysis of the residue, the average value $1.70 \mathrm{E} \neg 15$, mean $=\sim 0$, and std. dev. $=0.983 \sim 1$ indicate approximately standardized residuals, thus implying that the hypothesis of normal distribution model is not rejected.

Normal P-P Plot of Regression Standardized Residual

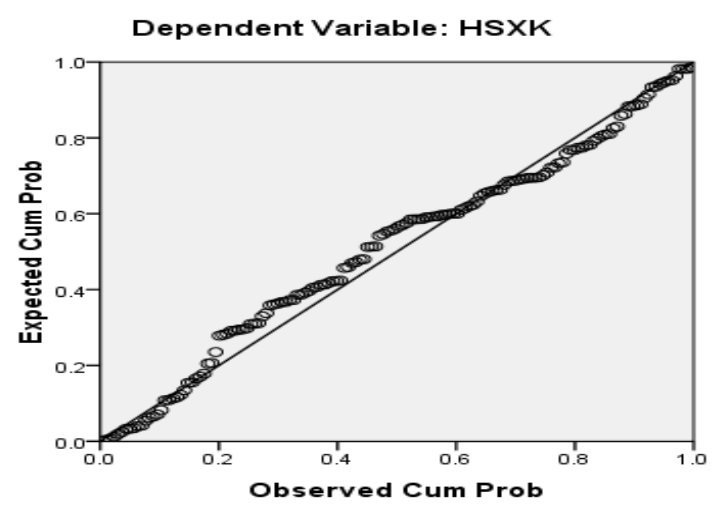

Figure 3. Normal P-P plot of regression standardized residual

\section{Assuming contact linear}

Considering the relationship between standardized residuals and predicted values through scatter plots, assuming a linear contact and equal variance is satisfactory; there is no contact between the predicted value and the part balance. It will be randomly 
distributed in a way around the vertical axis passing through zero and does not form a specific shape.

Scatterplot

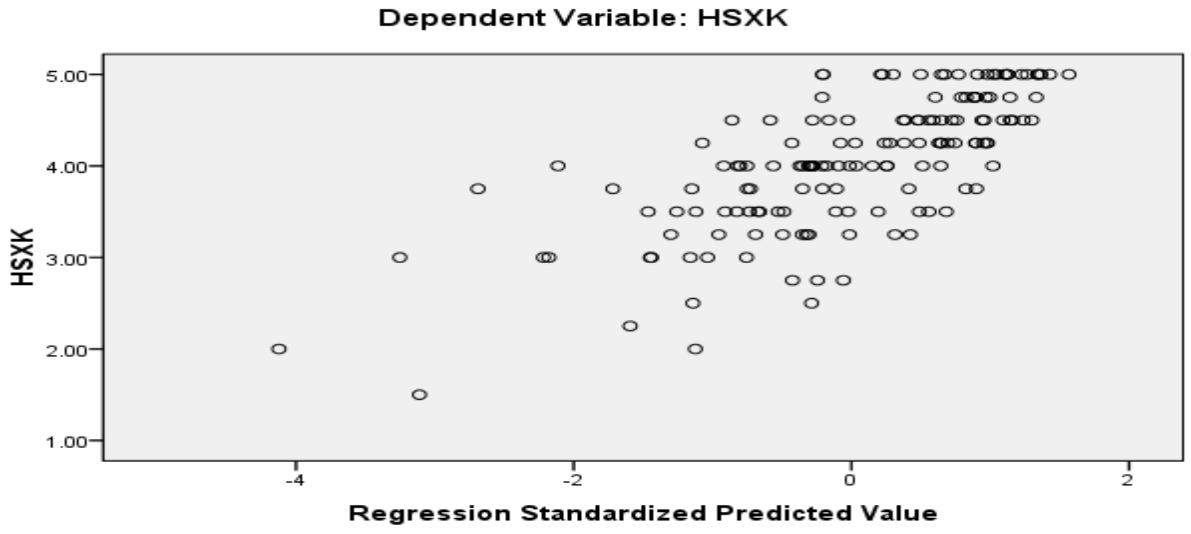

Figure 4. Regression standardized predicted value

\section{Result discussion}

The results confirm the negative relationship between product barrier and export performance $(\beta=-0.108$, sig $=0.032, \mathrm{t}=-1.513 \mathrm{p}=<0.05)$, which is consistent with the findings from most previous studies (Kaleka \& Katsikeas, 1995; Karelakis et al., 2008). However, while prior ones in the developed countries have shown the least importance of the product barrier (Moini, 1998; Leonidou, 2004), this study demonstrates it with the most significant impact on export performance of seafood companies in Vietnam.

Most of these only export a few types of product, such as shrimp, fish, or crab, as frozen raw products. In particular, since most are sold through foreign middlemen, and not to the ultimate consumers, this limits the ability to develop new products for specific foreign market's needs and wants, regardless of the diversity of consumer preferences across countries. In addition, although the production of high-value-added products is encouraged and aided by the Government, many firms seem to be afraid of the risks due to the lack of international market understanding.

The findings show a negative effect of price barrier on export performance $(\beta=-0.130$, $\operatorname{sig}=0.039, \mathrm{t}=-2.527, \mathrm{p}<0.05)$, which is similar to those of most previous studies 
(Moini, 1998; Leonidou, 2000). The price barrier is also found to be the second most important predictor of export performance in the industry. Although most seafood firms in Vietnam take advantage of the low labor cost, the price barrier is becoming more serious due to increasingly scarce materials and a polluted environment.

The present results also suggest a negative relationship between distribution barrier and export performance $(\beta=-0.222$, sig $=0.028, \mathrm{t}=-2.348, \mathrm{p}<0.05)$, which is compatible with those of previous studies (Leonidou et al., 2002; Moini, 1998). Although the distribution barrier's impact on export performance is weaker than that of product and price barriers in the industry, the magnitude of its effect is relatively strong. In fact, most export markets in the seafood industry are in developed countries. Therefore, firms have to face distribution channels consisting of many layers, direct distribution systems, and the diversity of the services required by distribution members across countries (Leonidou, 1995, 2000). This complexity of the distribution systems creates serious difficulties for these firms.

The findings also reveal a negative effect of the logistics barrier on export performance $(\beta=-0.156$, sig $=0.000, t=-4.097, \mathrm{p}<0.05)$, which is consistent with Katsikeas et al. (2008). Although the export revenue has continuously increased in recent years, the export markets of the firms focus mainly on the US, the EU, and Japan; the great geographical distance increases the transportation costs, limiting the ability to supply adequately. In addition, most of these firms have no warehousing facilities abroad. Thus, the flow of products to the host markets is not constant and is sometimes delayed. The characteristics of seafood products, which require special storage and faster transportation means, force the firms to pay extra costs. In most cases the seafood firms have to cover additional insurance, which increases the product prices imposed on endusers. Consequently, the logistics barrier diminishes the firms' competitiveness in international markets.

Finally, the results do not support a negative relationship between promotion barrier and export performance $(\beta=0.101, \mathrm{sig}=0.103, \mathrm{t}=1.643, \mathrm{p}>0.10)$, which is inconsistent with results of most previous studies (Koksal \& Kettaneh, 2011). However, it is worth noticing that although the effect of the promotion barrier on export performance is not significant, the promotion barrier correlates highly with other marketing barriers. Thus, its effect on export performance may occur indirectly through other ones, such as product, price, or distribution barriers. As a result, it would be a mistake to ignore the 
role of the promotion barrier in export performance. In fact, not many Vietnamese seafood firms can effectively carry out their promotion strategy abroad. What we can observe is that only a few ones introduce their products at expo exhibitions; some have a website to advertise and provide limited information about their products while others have no advertising activities in overseas markets due to high costs. These shortcomings generate risks for the firms when their export revenue is mainly based on a certain amount of familiar customers.

\section{Conclusion, implications, and suggestions for future studies}

\subsection{Conclusion}

This study has extended earlier studies (Kaynak \& Kothari, 1984; Leonidou, 2000) by analyzing and assessing the impact of trade barriers (product, price, distribution, logistics, and promotion) on export performance in a commercial industry featuring homogeneous distribution and production environments. Inheriting a few facets from previous studies, it mainly uses data in the fisheries industry of Vietnam.

\subsection{Implications for practical trading}

Several implications for the management of commercial and industrial sector can be offered as follows:

First, seafood firms should pay attention to various trade barriers based on different levels of impact to reduce or improve export performance. Despite the importance of each type of barriers, most of the aspects of the trade barriers play a certain role in the export performance. This means that managers and traders should have a comprehensive view of limitations of the barriers to the firm. A combination of tight link between the activities of the firm's staff members, a mechanism for sharing information, or the use of common resources can be good solutions to overcome institutional barriers to trade on the international market.

According to the findings from this study, enterprises should focus primarily on the barriers to product, price, distribution, logistics, and promotion. More importantly, for each type of trade barriers, they should determine the cause of each problem. For example, lack of knowledge and information about consumer attitudes, preferences, and habits may be the cause of the production's barely meeting the desired consumers' 
needs. Thus, a survey on consumer behavior in the target market can help solve this puzzle.

Finally, as mentioned in the introduction, the fisheries sector plays a very important role in the economy, especially in providing jobs for people and bringing a large amount of foreign currency for the country. Thus, policy makers in the fisheries industry should minimize the negative impact of trade barriers through workshops/seminars on how to improve strategic commercial mixture of seafood exporters, financial assistance, or expert consults aimed at more efficient export performance (Karelakis et al., 2008). Identification and evaluation of product marketing opportunities including product specifications for potential exports can be considered through the survey data. In recent years the Vietnam's seafood export industry has witnessed an exponential increase in value-added agriculture and food products. A larger sample size, which accurately reflects the seafood businesses, would identify product marketing opportunities more specifically. Regarding the objective to address transaction requirements for potential exports, the results indicate that high costs to exporting are perceived mainly by nonexporters. Few current exporters have cited costs, exchange rates, or record keeping as constraints to exporting besides trade barriers and tariffs that hindered export activities. Transaction costs such as exchange rates did, however, play a role in the withdrawal of former export participants from international markets.

\subsection{Policy implications}

Export assistance and promotion programs are designed to foster the Vietnamese seafood export industry, and those programs have evolved to focus on encouraging exports among SMEs. From a firm perspective the programs are developed to bridge information gaps about international markets and assist in the initial pursuit of these. The assistance programs for international marketing are available to seafood firms through the Vietnamese directorate of fisheries and trade associations like the Vietnam Association of Seafood Exporters and Processors (VASEP) in spite of the fact that among current exporters $63 \%$ did not use government assistance programs, stating that those were either useless or unknown to the firms. In addition, few studies have analyzed the efficiency of export promotion programs on the sustainability of exports among smaller businesses. Thus, the results of this research are useful for policymakers in designing trade policy. 


\subsection{Suggestions for further research}

Currently, research pertaining to the international involvement of the Vietnamese seafood export industry is limited. Additional information in this area will help identify the needs of the Vietnamese seafood for potential exports and the overall perception in the industry about international marketing. Further research will also benefit policymakers in the design of state export promotion and assistance programs. A more in-depth investigation is needed into the role of a firms' competitive advantage in international markets, and also into the conflict between export promotion programs and the "buy local, sell local" campaign.

Future studies would benefit from exploring other barriers (e.g., procedural, informational, or environmental ones) that affect export performance. The results presented here are based on self-reported measures of export performance relating to the Vietnamese seafood industry. Objective measures of export performance could also be used to increase the generalizability of the study.

Increasing the sample size for this study, following survey sampling protocol, will permit a more thorough analysis with the inclusion of additional variables and theories. A mail survey might be more efficient in increasing the sample size, and a comparison of response rates for different data collection methods among seafood businesses would be informative for researchers. The study could be enhanced by using case study and interview approaches to gather more information about the Vietnamese seafood businesses and food processors. Furthermore, further export research shall include a cost benefit analysis of export promotion policy in Vietnam

\section{References}

Aaby, N., \& Slater, S. F. (1989). Management influences on export performance: A review of the empirical literature 1978-1988. International Marketing Review, 6(4), 7-26.

Ahmed, Z. U., Julian, C. C., Baalbaki, I., \& Hadidian, T. V. (2004). Export barriers and firm internationalization: A study of Lebanese entrepreneurs. Journal of Management \& World Business Research, 1(1), 11-22.

Balabanis, G. I. (2000). Factors affecting export intermediaries' service offerings: The British example. Journal of International Business Studies, 31(1), 83-99.

Baldauf, A., Cravens, D. W., \& Wagner, U. (2000). Examining determinants of export performance in small open economies. Journal of World Business, 35(1), 61-79. 
Barney, J. (1991). Firm resources and sustained competitive advantage. Journal of Management, 17, 99-120.

Barrett, N. I., \& Wilkinson, I. F. (1985). Export stimulation: A segmentation study of the exporting problems of Australian manufacturing firms. European Journal of Marketing, 19(2), 53-72.

Bauerschmidt, A., Sullivan, D., \& Gillespie, K. (1985). Common factors underlying barriers to export: Studies in the US paper industry. Journal of International Business Studies, Fall, 111-123.

Bilkey, W. J. (1978). An attempted integration of the literature on the export behavior of firms. Journal of International Business Studies, Spring/Summer, 33-46.

Bilkey, W. J. (1982). Variables associated with export profitability. Journal of International Business Studies, 13, 39-55.

Carneiro, J., Rocha, A., \& Silva, J. F. (2011). Determinants of export performance: A study of large Brazilian manufacturing firms. Brazilian Administration Review, 8(2), 107-132.

Cheong, W. K., \& Chong, K. W. (1988). Export behaviour of small firms in Singapore. International Small Business Journal, 6(2), 34-41.

Czinkota, M. R., \& Ursic, M. L. (1983). Impact of export growth expectations on smaller firms. International Marketing Review, 1(2), 26-33.

da Silva, P. A., \& da Rocha, A. (2001). Perception of export barriers to Mercosur by Brazilian firms. International Marketing Review, 18(6), 589-610.

Falbe, C. M., \& Welsh, D. H. B. (1998). NAFTA and franchising: A comparison of franchisor perceptions of characteristics associated with franchisee success and failure in Canada, Mexico, and the United States. Journal of Business Venturing, 13(2), 151-171.

Gripsrud, G. (1990). The determinants of export decisions and attitudes to a distant market: Norwegian fishery exports to Japan. Journal of International Business Studies, 21(3), 469-485.

Gehlher, M., \& Dohlman, E. (2009). A weakening global economy interrupts agricultural trade. Amber Waves, 7(2), 22-29.

Hair, J., Anderson, R., Tatham, R., \& Black, W. (1998). Multivariate data analysis (5th Edition). NJ: Prentice-Hall Inc.

Hoang, T., \& Chu, N. M. N. (2008). Using SPSS for data analysis (in Vietnamese). Hanoi, Vietnam: Statistical Publishing House.

Howard, D. G., \& Borgia, D. (1990). Exporting and firm size: Do small exporters have special needs? Journal of Global Marketing, 4(1), 79-97.

Ibeh, K. I. N. (2004). Furthering export participation in less performing developing countries: The effect of entrepreneurial orientation and managerial capacity factors. International Journal of Social Economics, 31(1/2), 94-110.

Kaleka, A., \& Katsikeas, C. S. (1995). Exporting problems: The relevance of export development. Journal of Marketing Management, 5(3), 499-515. 
Karelakis, C., Mattas, K., \& Chryssochoidis, G. (2008). Export problems perceptions and clustering of Greek wine firms. Euro Med Journal of Business, 3(1), 6-22.

Katsikeas, C. S., Leonidou, L. C., \& Morgan, N. A. (2000). Firm-Level export performance assessment: Review, evaluation, and development. Journal of the Academy of Marketing Science, 28(4), 493-511.

Katsikeas, C. S., Leonidou, L. C., \& Samiee, S. (2008). Research into exporting: Theoretical, methodological, and empirical issues. In M. Kotabe \& K. Helsen (eds.), Handbook of international marketing (pp. 165-182). London: Sage Publications.

Kaynak, E., \& Kothari, V. (1984). Export behavior of small and medium-sized manufacturers: Some policy guidelines for international marketers. Management International Review, No. 2, 61-69.

Kedia, B. L., \& Chhokar, J. (1986). Factors inhibiting export performance of firms: An empirical investigation. Management International Review, 26(4), 33-43.

Keng, K. A., \& Jiuan, T. S. (1989). Differences between small and medium-sized exporting and nonexporting firms: Nature and nurture. International Marketing Review, 6(4), 27-40.

Koh, A. C. (1991). Relationships among organizational characteristics, marketing strategy, and export performance. International Marketing Review, 8(3), 46-60.

Koksal, M. H., \& Kettaneh, T. (2011). Export problems experienced by high- and low-performing manufacturing companies: A comparative study. Asia Pacific Journal of Marketing and Logistics, 23(1), 108-126.

Korth, C. M. (1991). Managerial barriers to US exports. Business Horizons, March-April, 18-26.

Lages, L. F., Sandy, D. J., \& David, A. G. (2008). The role of past performance in export ventures: A short-term reactive approach. Journal of International Business Studies, 39(2), 304-325.

Leonidou, L. C. (1995). Empirical research on export barriers: Review, assessment, and synthesis. Journal of International Marketing, 3(1), 29-43.

Leonidou, L. C. (2000). Barriers to export management: An organizational and internationalization analysis. Journal of International Management, 6(2), 1-28.

Leonidou, L. C. (2004). An analysis of the barriers hindering small business export development. Journal of Small Business Management, 42(3), 279-302.

Leonidou, L. C., Katsikeas, C. S., \& Samiee, S. (2002). Marketing strategy determinants of export performance: A meta-analysis. Journal of Business Research, 55(1), 51-67.

Matanda, M. J., \& Freeman, S. (2009). Effect of perceived environmental uncertainty on exporterimporter inter-organizational relationships and export performance improvement. International Business Review, 18, 89-107.

Moini, A. H. (1998). Small firms exporting: How effective are government export assistance programs. Journal of Small Business Management, 36(1), 1-15. 
Navarro, A., Losada, F., Ruzo, E., \& Diez, J. A. (2010). Implications of perceived competitive advantages, adaptation of marketing tactics and export commitment on export performance. Journal of World Business, 45(1), 49-58.

Ortega, S. (2003). Export barriers: Insights from small and medium-sized firms. International Small Business Journal, 21(4), 403-419.

Owusu-Frimpong, N., \& Mmeih, S. (2007). An evaluation of the perceptions and marketing practices of non-traditional exporters in Ghana. Thunderbird International Business Review, 49(1), 57-76.

Pett, T., \& Wolff, J. (2000). Internationalization of small firms: An examination of export competitive patterns, firm's size, and export performance. Journal of Small Business Management, 38(2), 3447.

Pett, T., \& Wolff, J. (2003). Firm characteristics and managerial perceptions of NAFTA: An assessment of export implications for US SMEs. Journal of Small Business Management, 41(2), $117-132$.

Papadopoulos, N., \& Martin, O. (2010). Toward a model of the relationship between internationalization and export performance. International Business Review, 19, 388-406.

Rabino, S. (1980). An aptitude evaluation of an export incentive program: The case of

DISC. Columbia Journal of World Business, 15, 61-65.

Ramaswami, S. N., \& Yang, Y. (1990). Perceived barriers to exporting and export assistance requirements. In S. T. Cavusgil \& M. R. Czinkota (eds.), International perspectives on trade promotion and assistance. Westport, CT: Quorum Books.

Suarez-Ortega, S. M. (2003). Export barriers: Insights from small and medium-sized firms. International Small Business Journal, 21(4), 403-419.

Shoham, A. (1999). Bounded rationality, planning, standardization of international strategy, and export performance: A structural model examination. Journal of International Marketing, 7(2), $24-50$.

Sousa, C. M. P., \& Bradley, F. (2008). Antecedents of international pricing adaptation and export performance. Journal of World Business, 43, 307-320.

Testom, G., \& Lutz, C. (2006). A classification of export marketing problems of small and medium sized manufacturing firms in developing countries. International Journal of Emerging Market, $1(3), 262-281$. 